\title{
Apoptosis and non-inflammatory phagocytosis can be induced by mitochondrial damage without caspases
}

\author{
MF van Delft ${ }^{1,2,3}$, DP Smith ${ }^{1}$, MH Lahoud ${ }^{1}$, DCS Huang ${ }^{1}$ and JM Adams ${ }^{*, 1}$
}

A central issue regarding vertebrate apoptosis is whether caspase activity is essential, particularly for its crucial biological outcome: non-inflammatory clearance of the dying cell. Caspase-9 is required for the proteolytic cascade unleashed by the mitochondrial outer membrane permeabilization (MOMP) regulated by the Bcl-2 protein family. However, despite the severely blunted apoptosis in cells from Casp9 ${ }^{-1-}$ mice, some organs with copious apoptosis, such as the thymus, appear unaffected. To address this paradox, we investigated how caspase-9 loss affects apoptosis and clearance of mouse fibroblasts and thymocytes. Although Casp ${ }^{-/-}$cells were initially refractory to apoptotic insults, they eventually succumbed to slower caspase-independent cell death. Furthermore, in $\gamma$-irradiated mice, the dying Casp9 ${ }^{-/-}$thymocytes were efficiently cleared, without apparent inflammation. Notably, MOMP proceeded normally, and the impaired mitochondrial function, revealed by diminished mitochondrial membrane potential $\left(\Delta \Psi_{m}\right)$, committed cells to die, as judged by loss of clonogenicity. Upon the eventual full collapse of $\Delta \Psi_{m}$, presumably reflecting failure of respiration, intact dying Casp9 ${ }^{-/-}$cells unexpectedly exposed the prototypic 'eat-me' signal phosphatidylserine, which allowed their recognition and engulfment by phagocytes without overt inflammation. Hence, caspase-9-induced proteolysis accelerates apoptosis, but impaired mitochondrial integrity apparently triggers a default caspase-independent program of cell death and non-inflammatory clearance. Thus, caspases appear dispensable for some essential biological functions of apoptosis.

Cell Death and Differentiation (2010) 17, 821-832; doi:10.1038/cdd.2009.166; published online 13 November 2009

The mode of cell death has major biological consequences. Whereas necrosis leads to plasma membrane rupture, release of pro-inflammatory intracellular molecules and collateral tissue damage, apoptosis removes redundant cells and maintains tissue homeostasis in a safe and nonimmunogenic manner. ${ }^{1}$ It precludes inflammation by confining noxious molecules within intact cell corpses marked for rapid recognition and clearance, typically by professional phagocytes such as macrophages and dendritic cells. ${ }^{2,3}$

Vertebrate apoptosis is regulated primarily by the $\mathrm{Bcl}-2$ protein family. ${ }^{4} \mathrm{Bcl}-2$ and close homologs keep the proapoptotic mediators Bax and Bak in check until developmental cues or imposed stresses activate the distantly related $\mathrm{BH}$ only proteins (e.g., Bim, Bad and Noxa). Their engagement of pro-survival relatives, and perhaps also Bax or Bak, allows Bax and Bak to oligomerize and permeabilize the mitochondrial outer membrane. The cytochrome $c$ released to the cytosol binds Apaf-1, which recruits caspase- 9 to form the apoptosome. Caspase- 9 can then cleave and activate the effector caspases-3, -6 and -7 , which dismantle the cell by cleaving vital intracellular substrates. ${ }^{5}$ Exposure on the cell corpse of molecules such as phosphatidylserine (PS) permits its non-inflammatory phagocytosis. ${ }^{2,3}$
Caspases are widely regarded as essential executors of vertebrate apoptosis because mice lacking caspase-9, ${ }^{6,7}$ Apaf- $1^{8,9}$ or both effector caspases-3 and $-7^{10}$ typically die before birth with abnormalities, most notably exencephaly, and their cells are refractory to many apoptotic stimuli. However, hematopoiesis, in which programmed cell death is abundant, appears normal in the absence of caspase- 9 or Apaf- $1,{ }^{11}$ or both caspases-3 and $-7,{ }^{10}$ and tissues with copious apoptosis, such as the thymus, show no inflammation. Thus, the ultimate objective of apoptosis, non-inflammatory cell clearance, might be achievable without caspases.

To investigate this paradox, we have analyzed further how thymocytes and fibroblasts lacking caspase- 9 die and are cleared. We find that they die by a caspase-independent cell death mechanism that follows mitochondrial outer membrane permeabilization (MOMP) and diminished mitochondrial membrane potential. Moreover, the cells with damaged mitochondria remained intact and, to our surprise, exposed PS on their surface, allowing their efficient phagocytosis. We conclude that caspase activation accelerates apoptosis but is not strictly required for loss of cell viability or non-inflammatory clearance of the corpses.

\footnotetext{
${ }^{1}$ The Walter and Eliza Hall Institute of Medical Research, 1G Royal Parade, Parkville, Victoria 3052, Australia and ${ }^{2}$ Department of Medical Biology, University of Melbourne, Melbourne, Australia

*Corresponding author: JM Adams, Molecular Genetics of Cancer Division, Walter and Eliza Hall Institute, 1G Royal Parade, Parkville, Victoria 3052, Australia. Tel: + 6139345 2555; Fax: + 6139347 0852; E-mail: adams@wehi.edu.au

${ }^{3}$ Current Address: Division of Cell and Molecular Biology, University Health Network, Toronto, Ontario, M5G 1L7, Canada

Keywords: apoptosis; mitochondrial membrane potential; Bcl-2 family; caspases; phosphatidylserine

Abbreviations: CFSE, carboxy-fluorescein diacetate succinimidyl ester; $\mathrm{DiOC}_{6}(3), 3,3^{\prime}$ dihexyloxacarbocyanine iodide; $\Delta \Psi_{\mathrm{m}}$, mitochondrial membrane potential; MEF, mouse embryo fibroblast; MOMP, mitochondrial outer membrane permeabilization; PI, propidium iodide; PS, phosphatidylserine

Received 31.7.09; revised 09.9.09; accepted 11.9.09; Edited by R Youle; published online 13.11.09
} 


\section{Results}

Apoptosis is markedly delayed but not ablated in Casp9 $^{-1-}$ thymocytes. Previous studies differ on the impact of caspase- 9 loss on hematopoietic cell death. In short-term assays, cells lacking caspase- 9 or Apaf- 1 were greatly resistant to apoptotic stimuli, ${ }^{6-9}$ but a study from this laboratory based largely on in vitro assays spanning several days found that they died at rates comparable with wild-type cells. ${ }^{11}$ We therefore compared the rates for wild-type, Casp $^{-/-}$and Bcl-2 transgenic thymocytes in both short- and long-term in vitro assays. As initially reported, ${ }^{6,7}$ at $24 \mathrm{~h}$ Casp $^{-/-}$thymocytes, unlike the wild-type cells, were largely refractory to $\gamma$-irradiation, etoposide, dexamethasone and phorbol myristate acetate (PMA), indeed virtually as resistant as the $\mathrm{Bcl}-2$ transgenic cells (Figure 1a, Supplementary Figure S1A). In extended assays, however, all these stimuli provoked considerably more death in $\mathrm{Casp}^{-1}$ thymocytes than $\mathrm{Bcl}-2$ transgenic counterparts (Figure 1b, Supplementary Figure S1B). Similarly, Casp $^{-1}$ thymocytes cultured ex vivo for up to 5 days without cytokines died at later times only moderately slower than wild-type counterparts and more rapidly than the $\mathrm{Bcl}-2$ transgenic cells (Figure 1c). Thus, caspase-9 accelerates the thymocyte death caused by apoptotic stresses but is not essential.

The death of Casp9 $^{-/}$cells does not rely upon residual caspase activation. As expected, the Casp $9^{-/-}$thymocytes showed far less caspase activity than the wild-type cells. After $\gamma$-irradiation, active caspases were robustly labeled with a biotinylated irreversible caspase inhibitor (biotin-XVAD-fmk) in lysates of wild-type thymocytes but far less so in Casp9 ${ }^{-/}$ lysates (Figure 2a). Indeed, quantitative western blots and fluorogenic substrate assays indicated that the Casp9 ${ }^{-1-}$ thymocytes had only $\sim 3 \%$ as many active caspase molecules as wild-type counterparts (Supplementary Figure S2). To identify the active caspases, we isolated the biotinylated polypeptides with streptavidin resin and probed them with specific antibodies. Whereas the wild-type thymocytes yielded active caspases-1, -2, -3, -7, -8, -11 and -12 (Figure $2 b$ ), most of which were probably activated by the abundant active caspases-3 and -7, the Casp9 ${ }^{-1}$ thymocytes yielded small amounts of active caspases- 3 and -7 , but no others were detectable (Figure $2 b$ ).

To determine whether the residual effector caspase activity drove the death of irradiated Casp $9^{-/-}$thymocytes, we tested the impact of two broad-spectrum caspase inhibitors. Both effectively inhibited apoptosis in wild-type thymocytes but the marginal increase in the viability of the $\operatorname{Casp}^{-/}$thymocytes was comparable with that in untreated cultured cells (Supplementary Figure S3A). Hence, none of the two compounds specifically inhibited their $\gamma$-irradiation-induced death (Figure 2c), and even their 'spontaneous death' in culture was only slightly delayed by caspase inhibition (Supplementary Figure S3B). Therefore, the death of $\mathrm{Casp9}^{-1-}$ thymocytes is not attributable to residual active effector caspases.

We also evaluated apoptosis in Casp9 ${ }^{-1-}$ mouse embryonic fibroblasts (MEFs), using either a cytotoxic stimulus that evokes DNA damage (etoposide) or signals that directly neutralize all of the Bcl-2-like pro-survival proteins: ${ }^{12}$
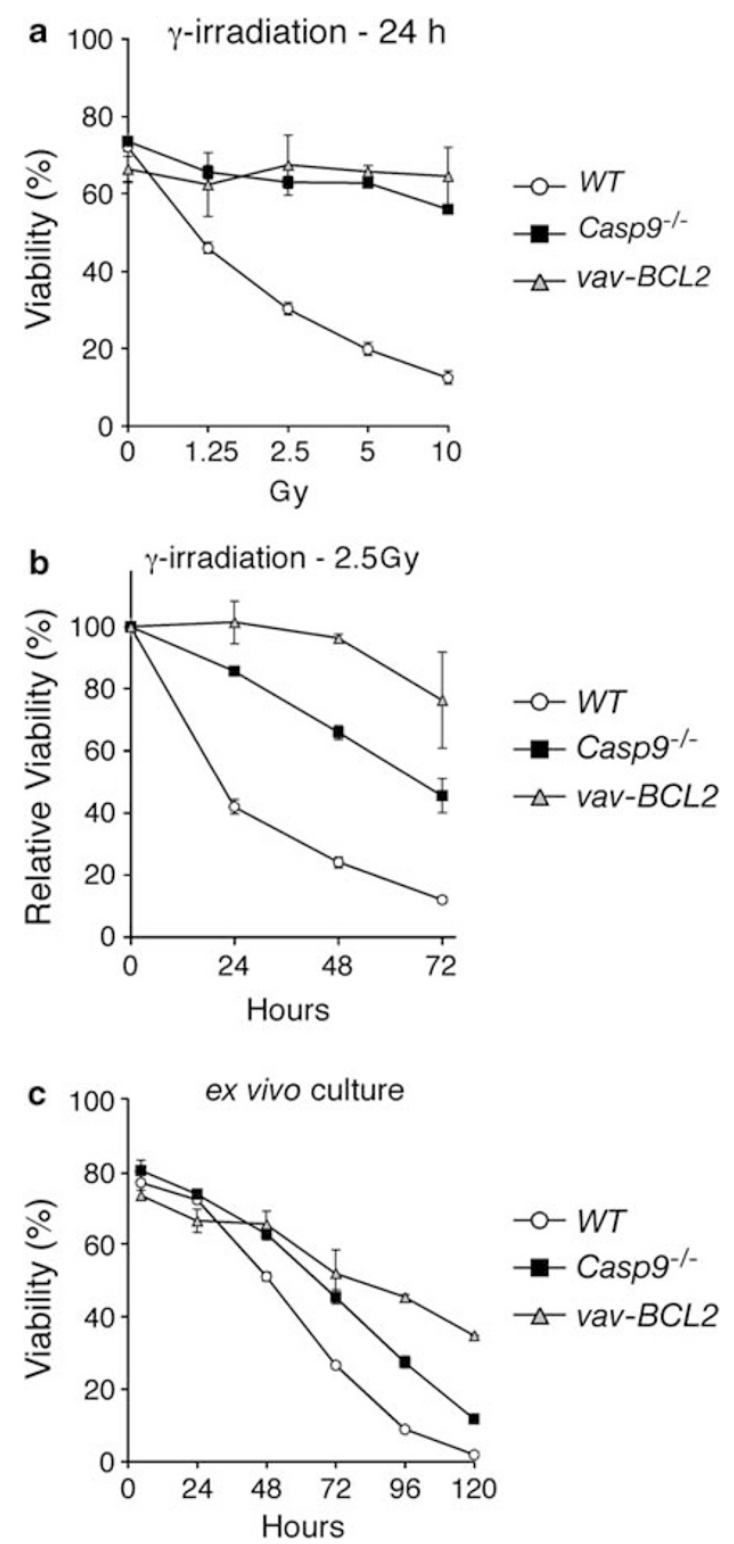

Figure 1 Apoptosis is impaired in Casp $9^{-/-}$thymocytes. Thymocytes of the indicated genotypes were cultured ex vivo and, where indicated, exposed to $\gamma$-irradiation to provoke apoptosis. Cell viability was determined by staining with PI. The data are presented as means \pm S.E.M. (WT, $n=8$; Casp9 $^{-1-}, n=6$; vav-Bcl2, $n=2$ ). (a) Cell viability was measured $24 \mathrm{~h}$ after exposure to the indicated doses of $\gamma$-irradiation. (b) Cell viability was measured at the indicated times after exposure to $2.5 \mathrm{~Gy} \gamma$-irradiation, and the data plotted as percentage of viability relative to untreated cells cultured ex vivo for the same time. (c) Cell viability was measured after the indicated periods of ex vivo culture without cytokine support

(a) expression of the potent $\mathrm{BH} 3-o n l y$ protein $\mathrm{Bim}$, or (b), exposure of cells overexpressing the selective BH3-only protein Noxa to the Bad-like BH3 mimetic ABT-737. ${ }^{13}$ In shortterm assays, Casp9 ${ }^{-1-}$ MEFs were refractory to all three insults (Supplementary Figure S4A) and their death was modest even over several days (Supplementary Figure S4B). Moreover, no substantial effector caspase activation was evident in the Casp9 ${ }^{-1-}$ MEFs (Supplementary Figure S4C), and broad-spectrum caspase inhibitors did not block their death (Supplementary Figure S4D). Thus, like the mutant 
a

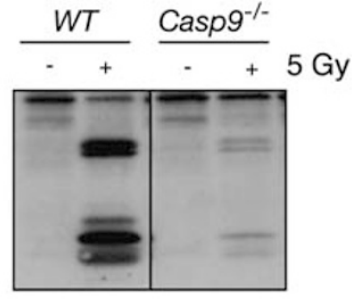

WB: HRP-streptavidin

b
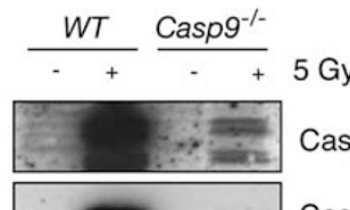

Casp-7
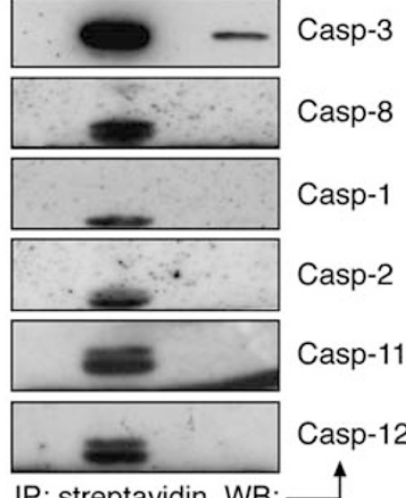

IP: streptavidin, WB:

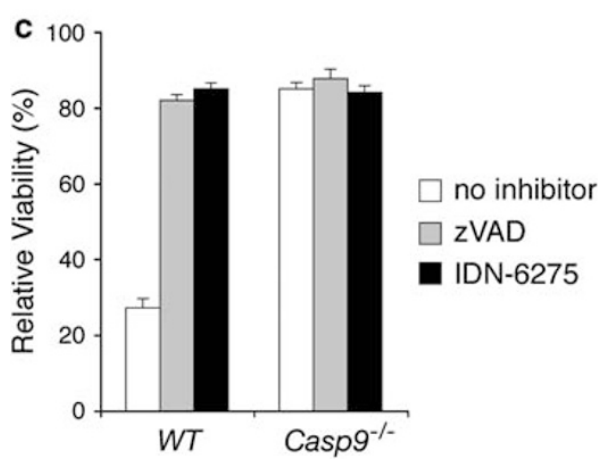

Figure 2 Caspase activation is impaired in Casp9 $^{-1}$ thymocytes and contributes little to their ultimate death. (a and $\mathbf{b})$ Lysates were prepared from WT and Casp9 ${ }^{-1-}$ thymocytes that had been either left untreated or exposed to $5 \mathrm{~Gy}$ of $\gamma$-irradiation and then cultured for $8 \mathrm{~h}$. Active caspases were labeled with an irreversible biotinylated caspase inhibitor (biotin-XVAD-fmk, where $\mathrm{X}$ is a flexible linker between the biotin and VAD-fmk groups). In (a) the labeled caspases were resolved by SDS-PAGE, and detected by blotting with HRP-streptavidin. In (b) the labeled (active) caspases were purified with streptavidin resin, eluted, resolved by SDS-PAGE and blotted with antibodies recognizing the active subunits of the indicated caspases. (c) WT and Casp $9^{-/-}$thymocytes were either left untreated or exposed to $5 \mathrm{~Gy}$ of $\gamma$-irradiation and then cultured in the presence of $50 \mu \mathrm{M} \mathrm{zVAD}$ fmk, $50 \mu \mathrm{M}$ IDN-6275, or no caspase inhibitor. Cell viability was measured after $24 \mathrm{~h}$ by PI staining. The data are shown as percentage of viability of irradiated cells relative to untreated cells cultured for the same time in the presence of the indicated caspase inhibitor to show that the inhibitors do not block the apoptosis induced specifically by the irradiation. The data are presented as means \pm S.E.M. from three independent experiments. The absolute cell viabilities measured in these experiments are presented in Supplementary Figure S3A thymocytes, the Casp $9^{-/-}$MEFs died slowly by a caspaseindependent pathway.

The different apoptotic stages regulated by $\mathrm{Bcl}-2$ and caspases are discernable by mitochondrial membrane potential. Bcl-2 preserves mitochondrial integrity and hence function, whereas caspase- 9 acts downstream of MOMP. To assess mitochondrial function during apoptosis, we used the potentiometric dye 3,3'-dihexyloxacarbocyanine iodide $\left(\mathrm{DiOC}_{6}(3)\right)$ to monitor changes in mitochondrial membrane potential $\left(\Delta \Psi_{\mathrm{m}}\right)$, a hydrogen ion gradient across the inner membrane that is coupled to oxidative phosphorylation. ${ }^{14}$

We first compared wild-type and Casp $9^{-/}$MEFs, Casp9 $9^{-/}$ MEFs stably overexpressing $\mathrm{Bcl}-2$, and MEFs lacking the essential pro-apoptotic proteins Bax and Bak. Each initially displayed a small transient increase in $\Delta \Psi_{\mathrm{m}},{ }^{15}$ which was complete within $2 \mathrm{~h}$ (Supplementary Figure S5). Their subsequent $\Delta \Psi_{\mathrm{m}}$ depended on their genetic constitution. Wild-type MEFs lost $\Delta \Psi_{\mathrm{m}}$ completely within $48 \mathrm{~h}$, and their plasma membranes concomitantly became permeable, as detected by propidium iodide (PI) uptake (Figure 3a). Thus, over time, the viable $\left(\mathrm{PI}^{-\mathrm{ve}}\right)$ wild-type cells, shown by filled histograms, were replaced by dead $\left(\mathrm{PI}^{+\mathrm{ve}}\right)$ cells, shown by the unfilled histograms. In contrast, most Casp9 ${ }^{-1-} \mathrm{MEFs}$ remained intact, and unexpectedly acquired an intermediate $\Delta \Psi_{\mathrm{m}}$, which was maintained in the majority of cells for at least $48 \mathrm{~h}$ in Figure $3 \mathrm{a}$ and at least $72 \mathrm{~h}$ in another experiment (data not shown). Bcl-2 overexpression in the Casp9 $^{-/}$MEFs prevented this initial $\Delta \Psi_{\mathrm{m}}$ decline, as did the absence of both Bax and Bak (Figure 3a). In contrast, broad-spectrum caspase inhibitors failed to prevent the initial $\Delta \Psi_{\mathrm{m}}$ drop in either the wild-type or Casp $9^{-1-}$ MEFs but did prevent the further $\Delta \Psi_{m}$ collapse in the wild-type MEFs (Figure 3b).

Similarly, in $\gamma$-irradiated thymocytes, $\mathrm{Bcl}-2$ overexpression prevented the initial fall in $\Delta \Psi_{\mathrm{m}}$, whereas caspase-9 loss or caspase inhibition prevented only the further complete loss of $\Delta \Psi_{\mathrm{m}}$ (Figure 3c). The thymocytes were less robust than the MEFs. At $24 \mathrm{~h}$ after irradiation only $38 \%$ of the Casp $^{-1-}$ thymocytes persisted with an intermediate $\Delta \Psi_{\mathrm{m}}$ (Figure 3c), and by $48 \mathrm{~h}$ only $20 \%$ remained viable (data not shown).

We hypothesized that the initial drop in $\Delta \Psi_{m}$ resulted from MOMP and that the rapid subsequent $\Delta \Psi_{\mathrm{m}}$ collapse in the wild-type cells was caspase-mediated (Figure $3 d$ ). Indeed, a flow cytometric sort of stressed MEFS by $\Delta \Psi_{\mathrm{m}}$ revealed that cytochrome $c$ had been released in cells with intermediate $\Delta \Psi_{\mathrm{m}}$ but not those retaining high $\Delta \Psi_{\mathrm{m}}$ (Figure 4a). Furthermore, when we neutralized all the $\mathrm{Bcl}-2$ pro-survival proteins in Casp9 ${ }^{-/}$MEFs with Noxa plus ABT-737, cytochrome $c$ release preceded the drop to intermediate $\Delta \Psi_{\mathrm{m}}$ by $0.5 \mathrm{~h}$ (Figure 4b).

Thus, $\Delta \Psi_{\mathrm{m}}$ decreases in two discrete steps during apoptosis (Figure $3 \mathrm{~d}$ ). The intermediate $\Delta \Psi_{\mathrm{m}}$ results from MOMP, because that decline requires pro-apoptotic Bax or Bak but not caspases, is inhibited by $\mathrm{Bcl}-2$ and shortly follows cytochrome $c$ release. The later complete collapse of $\Delta \Psi_{\mathrm{m}}$ (depolarization) probably reflects cessation of respiration (see the Discussion section), and its acceleration in the wild-type cells may well reflect destruction of electron transport components by effector caspases. ${ }^{16}$ 



d

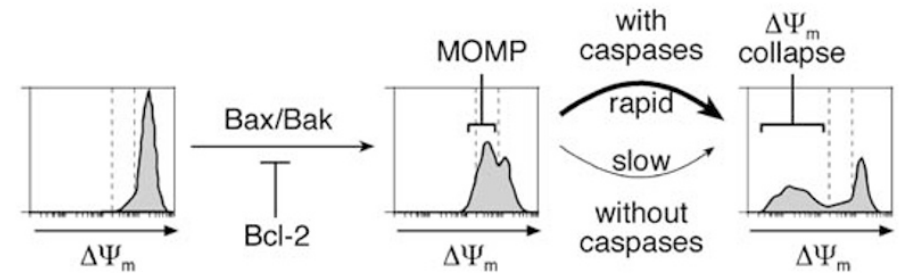

Figure $3 \mathrm{Bcl}-2$ and caspases control distinct stages of mitochondrial dysfunction. In all panels, the three levels of staining with DiOC 6 (3) observed during apoptosis $\left(\Delta \Psi_{\mathrm{m}}^{\text {high }}, \Delta \Psi_{\mathrm{m}}^{\text {intermediate }}\right.$ and $\left.\Delta \Psi_{\mathrm{m}}^{\text {low }}\right)$ are delineated by the dashed vertical lines on the histograms, and the percentages of total cells having each level are indicated. In (a-c), the $\mathrm{Pl}^{- \text {ve }}$ (intact) and $\mathrm{PI}^{+\mathrm{ve}}$ (dead) cell populations were gated separately; the intact cells were plotted as thin lines with gray fill and the dead cells by a bold line without fill. (a) WT, Casp9 ${ }^{-1-}$, and $\mathrm{Bax}^{-1-} \mathrm{Bak}^{-1-} \mathrm{MEFs}$ and $\mathrm{Casp9}^{-/-} \mathrm{MEFs}$ stably overexpressing Bcl-2 were exposed to $50 \mu \mathrm{M}$ etoposide, stained with $\mathrm{PI}$ and DiOC ${ }_{6}(3)$ after the indicated times and analyzed by FACS. (b) WT and Casp9 ${ }^{-1-}$ MEFs were cultured in the presence of $50 \mu \mathrm{M}$ etoposide plus $50 \mu \mathrm{M}$ zVAD-fmk, $50 \mu \mathrm{M}$ IDN-6275, or no caspase inhibitor. The cells were stained and analyzed as in (a). (c) WT, Casp ${ }^{-1-}$ and vav-Bcl-2 transgenic thymocytes were either left untreated or exposed to 5 Gy of $\gamma$-irradiation and then cultured in the presence of either $50 \mu \mathrm{M} \mathrm{IDN}-6275$ or no caspase inhibitor for $24 \mathrm{~h}$. The cells were stained and analyzed as in (a). (d) Model of the observed changes in $\Delta \Psi_{\mathrm{m}}$ during apoptosis

MOMP commits the cells to die. To determine whether MOMP commits the cells to die, we first exposed Casp $9^{-1-}$ MEFs expressing Noxa to graded concentrations of ABT-737 and measured both $\Delta \Psi_{\mathrm{m}}$ and clonogenic potential. Indeed, the drop to an intermediate $\Delta \Psi_{\mathrm{m}}$ correlated strongly with reduced colony formation (Figure $5 \mathrm{a}$ ). Moreover, when we sorted the stressed MEFs by $\Delta \Psi_{\mathrm{m}}$, those retaining high $\Delta \Psi_{\mathrm{m}}$ formed colonies comparably with untreated cells, whereas those of intermediate $\Delta \Psi_{\mathrm{m}}$ yielded none (Figure $5 \mathrm{~b}$ ). The common apoptotic stimulus staurosporine gave equivalent results (Supplementary Figure S6). Thus, MOMP commits MEFs to die, as reported for immortal hematopoietic cells and mast cells. ${ }^{17,18}$

The impaired mitochondrial function (Figure 3) and loss of clonogenicity (Figure 5) in the stressed Casp9 ${ }^{-1-}$ cells can explain why overexpressed Bcl-2, but not caspase- 9 loss 

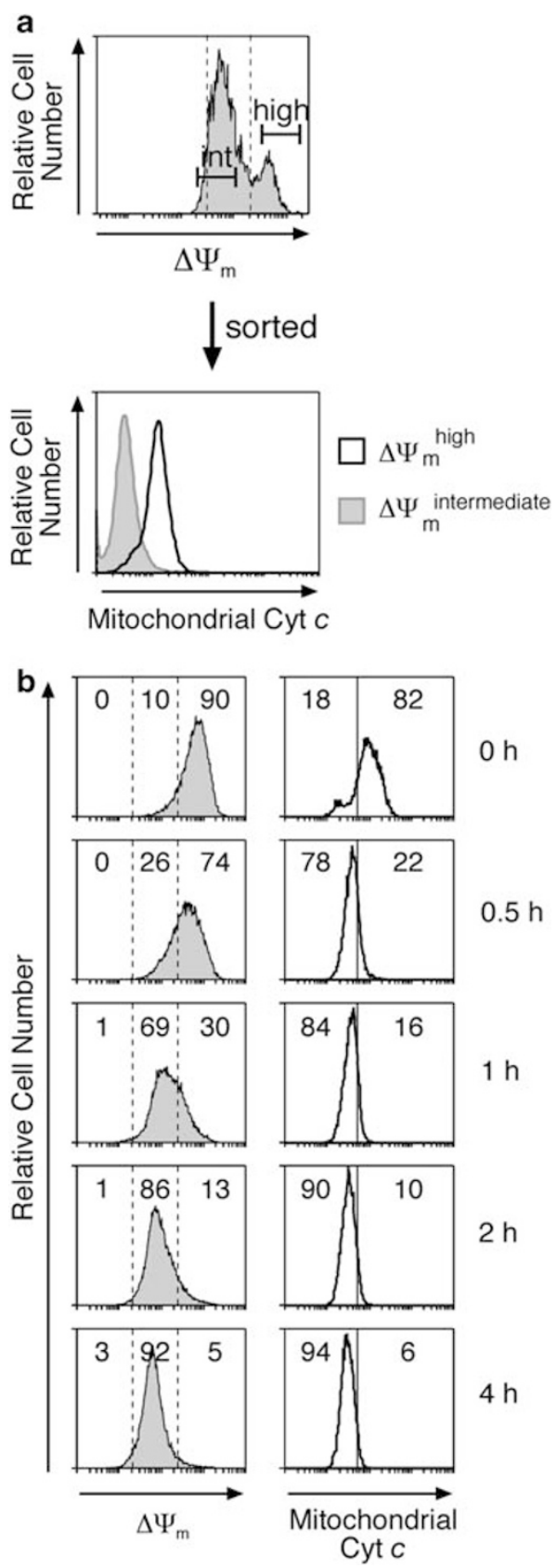

Figure 4 The Bcl-2-regulated drop to intermediate $\Delta \Psi_{\mathrm{m}}$ follows MOMP as judged by cytochrome $c$ release. (a) Casp $9^{-1-}$ MEFs exposed to $50 \mu \mathrm{M}$ etoposide for $30 \mathrm{~h}$ were stained with $\operatorname{DiOC}_{6}(3)$ and sorted into $\Delta \Psi_{\mathrm{m}}^{\text {high }}$ and $\Delta \Psi_{\mathrm{m}}^{\text {intermediate }}$ populations, each of which was permeabilized with digitonin to remove cytosolic cytochrome $c$, fixed with formaldehyde and stained with an anti-cytochrome $c$ antibody to reveal mitochondrial cytochrome $c^{42}$ (b) Casp9 ${ }^{-1-}$ MEFs stably expressing Noxa were exposed to $2.5 \mu \mathrm{M}$ ABT-737 and cultured for the indicated times. The cells were either stained with $\mathrm{DiOC}_{6}(3)$ or with an anti-cytochrome $c$ antibody as in (a). The percentages of cells in the gated regions of the histograms are indicated. Note that most mitochondrial cytochrome $c$ was released by $0.5 \mathrm{~h}$ but a comparable drop in $\Delta \Psi_{m}$ required $1-2 \mathrm{~h}$

prolongs lymphocyte survival in vivo. ${ }^{11}$ But if Casp9 $^{-/-}$cells do not undergo caspase-dependent apoptosis, how are they properly cleared from the animal?
Dying Casp9 ${ }^{-1-}$ thymocytes are efficiently cleared by phagocytes in vivo. Non-inflammatory clearance of wildtype cells is ensured by their exposure of PS. ${ }^{2,3}$ Genetic lesions or agents that interfere with PS-mediated clearance lead within 6 weeks to anti-nuclear autoantibodies in the serum, perhaps because secondary necrosis of the lingering cells creates a pro-inflammatory milieu that breaks selftolerance. ${ }^{19,20}$ However, no anti-nuclear antibodies appeared in the sera of mice up to 20 weeks after reconstitution with Casp $9^{-1-}$ hematopoietic stem cells (Supplementary Figure S7). This finding, combined with the normal cellular composition and lack of inflammation in hematopoietic organs, ${ }^{11}$ suggests that dying Casp $^{-/-}$cells must be removed appropriately.

To test directly whether Casp $9^{-1-}$ cells are efficiently cleared in vivo, we monitored thymocyte cell death and clearance from reconstituted mice exposed to whole-body $\gamma$-irradiation, which decimates the wild-type thymus. Whereas wild-type thymocytes, particularly the exquisitely sensitive $\mathrm{CD}^{+}{ }^{+} \mathrm{CD} 8{ }^{+}$cells, plummeted in number, the loss of Casp9 $^{-1-}$ thymocytes was delayed (Figure $6 a$ and b). Nevertheless, by $24 \mathrm{~h}, \sim 85 \%$ of them had been successfully cleared (Figure 6a), and histological sections of both $\mathrm{Casp9}^{-1-}$ and wild-type thymi revealed dramatically fewer lymphocytes (Figure 6c). Moreover, the proportion of thymic TUNEL + ve macrophages $\left(C D 11 b^{+v e}\right)$, that is, those that have engulfed apoptotic thymocytes, ${ }^{21}$ increased substantially following irradiation of both wild-type and $\mathrm{Casp9}^{-/}$reconstituted animals (Figure 6d). Hence, Casp9 ${ }^{-1-}$ thymocytes must still display signals that promote their phagocytosis.

Dying Casp9 ${ }^{-/}$thymocytes display PS before they lose plasma membrane integrity. PS, detected by staining with Annexin $\mathrm{V}$, is the best characterized molecule that marks apoptotic cells for phagocytosis. ${ }^{3}$ Its exposure is widely thought to be caspase-dependent, ${ }^{5,22}$ although there are reported examples of caspase-independent PS translocation. $3,23-25$ Indeed, we noted that even though Casp $9^{-/}$cells die with little or no caspase contribution (Figure 2, Supplementary Figures S2 and S3), they still exposed PS before losing plasma membrane integrity, that is, becoming $\mathrm{PI}^{+ \text {ve }}$ (Figure 7a). Furthermore, a broadspectrum caspase inhibitor did not block the PS exposure (Figure 7b). Caspase activity is not, therefore, essential for intact dying cells to expose PS. Like cells undergoing conventional apoptosis, at any one time, only a small proportion of the cells ( $\sim 5$ to $10 \%$ ) were Annexin $\mathrm{V}^{+\mathrm{ve}}$ $\mathrm{PI}^{-v e}$, but it seems likely that most or all pass through that state.

Interestingly, we identified a striking association between PS exposure and $\Delta \Psi_{m}$ collapse. Staining simultaneously for plasma membrane integrity (with $\mathrm{PI}), \Delta \Psi_{\mathrm{m}}$ and $\mathrm{PS}$ exposure revealed that nearly all wild-type and Casp $9^{-1-}$ cells with intact plasma membranes and exposed PS had lost $\Delta \Psi_{\mathrm{m}}$, as indicated by the $\mathrm{PI}^{-v e}$ Annexin $\mathrm{V}^{+\mathrm{ve}}$ (green) population (Figures 7c and d). Conversely, all the cells with an intact plasma membrane that lacked exposed PS, namely the $\mathrm{Pl}^{-v e}$ Annexin $\mathrm{V}^{-\mathrm{ve}}$ (blue) population, displayed either full or intermediate $\Delta \Psi_{\mathrm{m}}$. Thus, in both Casp $^{-/-}$and wild-type cells, PS exposure is tightly correlated with collapse of $\Delta \Psi_{m}$. 
a

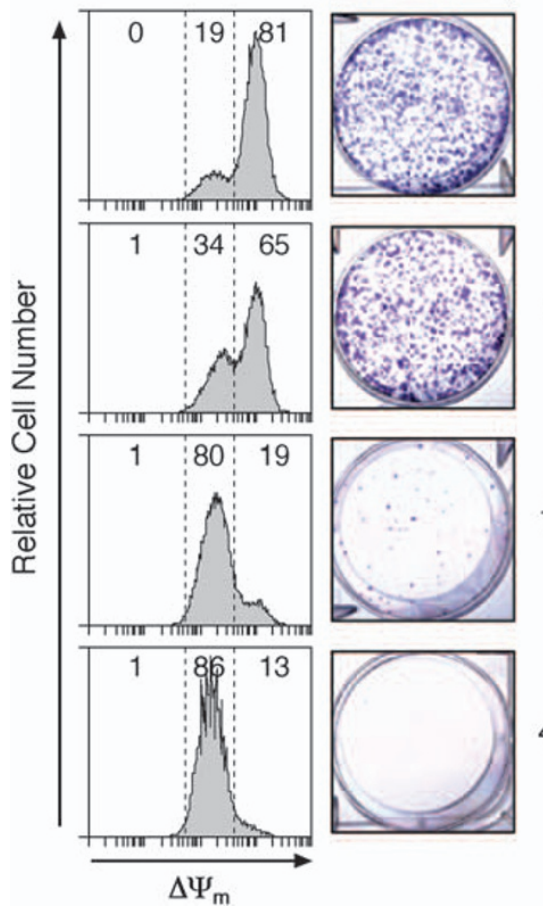

b

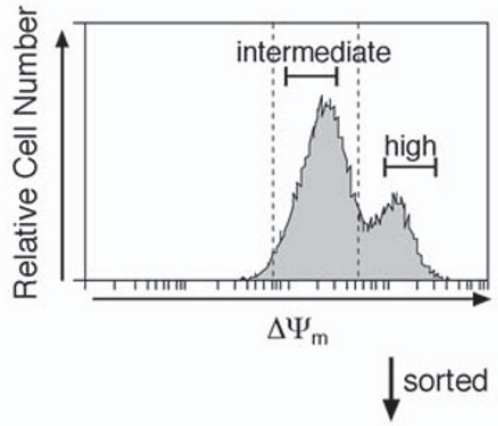

160
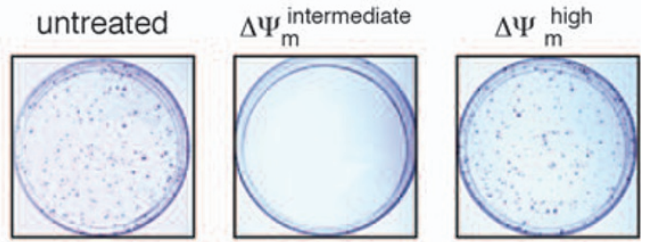

400

Figure 5 MOMP provokes loss of cell viability in clonogenic assays. (a) Casp $9^{-/-}$MEFs stably expressing Noxa were exposed to the indicated concentrations of ABT-737 for $24 \mathrm{~h}$ and then either stained with $\mathrm{DiOC}_{6}(3)$ and analyzed by FACS, or washed, replated and cultured for 7 days to allow colonies to form. (b) Casp9 ${ }^{-1-}$ MEFs stably expressing Noxa were exposed to $125 \mathrm{nM} \mathrm{ABT}-737$ for $24 \mathrm{~h}$, stained with $\operatorname{DiOC}_{6}(3)$ and sorted into $\Delta \Psi_{\mathrm{m}}^{\text {high }}$ and $\Delta \Psi_{\mathrm{m}}^{\text {intermediate }}$ populations. The sorted cells and untreated control cells were seeded at equal cell densities and cultured for 7 days to allow colonies to form

Because PS exposure precedes the loss of plasma membrane integrity, it may well flag the intact corpses for efficient non-inflammatory clearance in vivo.

Phagocytes recognize and engulf only Casp9 $^{-1-}$ cells that expose PS. Two other signals on some dying wild-type cells that influence phagocytosis are exposure of the 'eat-me' signal calreticulin and reduced expression of the 'don't-eatme' signal CD47, ${ }^{26}$ although whether these alterations require caspases or are linked to PS exposure is unknown. We tested whether dying Casp $^{-/-}$cells (i.e., those that have undergone MOMP and thus cannot proliferate but have not yet exposed PS - designated hereafter as 'moribund') showed these changes. Neither signal, however, discriminated between moribund and healthy Casp9 ${ }^{-1-}$ cells. Whereas apoptotic wild-type cells exposed calreticulin on their surface, ${ }^{26}$ moribund Casp $^{-/-}$cells did not (Figure 8a). Similarly, although apoptotic wild-type cells had reduced expression of CD47, moribund Casp9 $^{-1-}$ cells maintained normal levels, and it remained fully competent to bind its phagocyte receptor SIRP $\alpha$ (Figure 8a). These differences suggest that both the exposure of calreticulin and reduced surface CD47 expression on apoptotic cells are directly or indirectly provoked by caspase activity. Moreover, these changes must either coincide with or occur downstream of PS exposure.

To test functionally whether PS exposure was critical for phagocytosis of dying Casp9 ${ }^{-/-}$cells, we adopted an in vitro assay, using as targets irradiated thymocytes labeled with the dye carboxy-fluorescein diacetate succinimidyl ester (CFSE).
We first confirmed that macrophages engulfed in a temperature-dependent manner not only apoptotic wild-type cells but also Casp $^{-1-}$ thymocytes, albeit less efficiently (Figures 8b and c). Significantly, however, irradiated Casp9 ${ }^{-1-}$ thymocytes bearing surface PS were phagocytosed as efficiently as wild-type counterparts, whereas the moribund $\mathrm{PS}^{-\mathrm{ve}}$ cells were as refractory to engulfment as healthy $\mathrm{PS}^{-\mathrm{ve}}$ cells (Figure 8d). We conclude that Casp $9^{-/-}$cells are engulfed when they have redistributed PS to their surface, and thus that surface PS represents a critical signal for their clearance.

\section{Discussion}

The paramount function of apoptosis is to remove redundant cells without inducing inflammation. ${ }^{1}$ We have examined how loss of caspase-9, a critical component of the intrinsic apoptotic pathway, impacts on that function. Although nearly all hallmarks of apoptosis are ascribed to caspases, ${ }^{5}$ blocking their action has surprisingly limited the effects in the animal. The defects in embryos lacking caspase-9, Apaf-1 or both effector caspases -3 and -7 are confined to select organs. ${ }^{6-10}$ Remarkably, the mutant hematopoietic organs, including those with abundant apoptosis such as the thymus, show normal cellularity and composition. ${ }^{10,11}$

An earlier study from our laboratory noted the residual caspase activity in dying Casp $^{-/-}$cells and hypothesized that alternative $\mathrm{Bcl}$-2-regulated initiator caspases might still drive caspase-dependent apoptosis. ${ }^{11}$ That hypothesis now appears unlikely, because lymphocytes are not elevated by the knockout of any individual initiator caspase, nor even the 
a

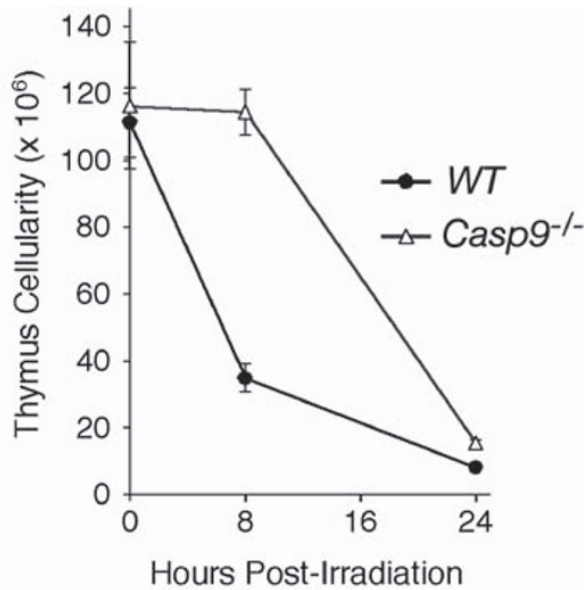

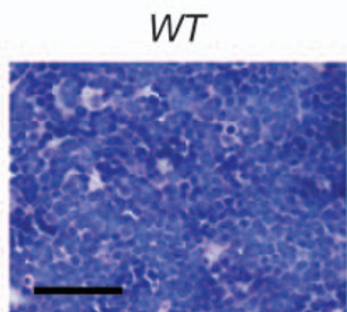
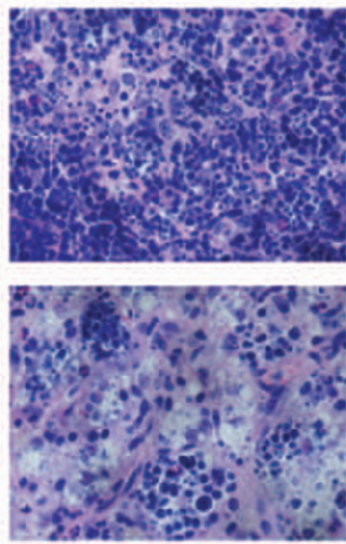

WT

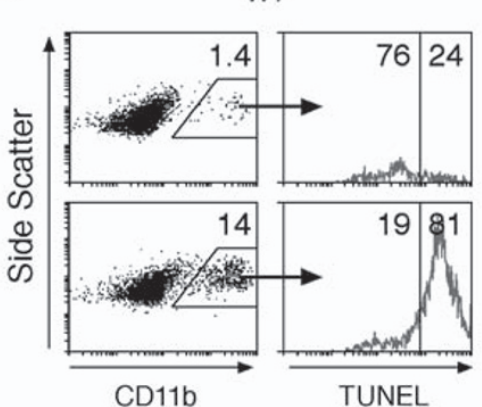

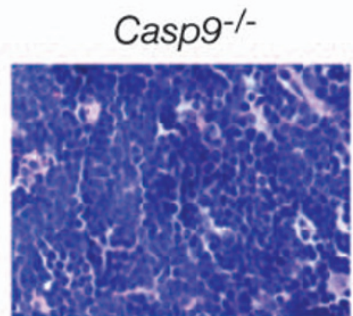

$\mathrm{Oh}$

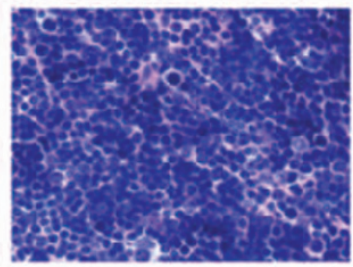

$8 \mathrm{~h}$

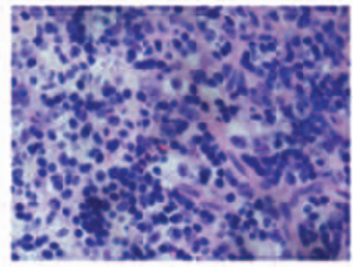

$24 \mathrm{~h}$ b

CD4


CD8
$8 \mathrm{~h}$

$24 \mathrm{~h}$

Figure 6 Dying Casp ${ }^{-/-}$thymocytes are removed by phagocytes in vivo, albeit more slowly. Ly5.1 recipient mice whose hemopoietic system had been reconstituted for 11-15 weeks with fetal liver stem cells from wild-type or $\mathrm{Casp}^{-1-}$ Ly5.2 donors were exposed to 5 Gy whole-body $\gamma$-irradiation. The mice were killed at 0,8 and $24 \mathrm{~h}$ postirradiation. $n=3$ animals of each genotype at each time point. (a) Thymic cellularity was determined by enumerating the cells recovered from the harvested thymi. Data are presented as means \pm S.E.M. (b) Thymic cell subset composition was determined by staining with anti-CD4 and anti-CD8 antibodies. The percentage of cells in each quadrant is indicated. (c) Representative hematoxylin- and eosin-stained sections of thymi at different times post-irradiation. Scale bar $=50 \mu \mathrm{m}$. (d) Cells recovered from the harvested thymi were co-stained with anti-CD11b (Mac1) antibodies and TUNEL. The histograms show TUNEL signal on the gated CD11b ${ }^{+v e}$ cells. The percentages of gated ${\mathrm{CD} 11 \mathrm{~b}^{+\mathrm{ve}} \text { cells are shown on the dot plots. The histograms indicate the percent of TUNEL }}^{-v e}$ and TUNEL ${ }^{+v e}$ cells in the gated CD11b ${ }^{+v e}$ population

combined loss of caspases 2 and $9,{ }^{27}$ or caspases 1,11 and 9 (DPS, MFvD and JMA, unpublished results), whereas lymphopoiesis is grossly perturbed when MOMP is blocked by the absence of both $\mathrm{Bax}$ and $\mathrm{Bak}^{28}$ or by $\mathrm{Bcl}-2$ overexpression. ${ }^{11}$ Furthermore, we detected no active initiator caspase in irradiated $\mathrm{Casp9}^{-1-}$ thymocytes (Figure 2b). Traces of active effector caspase- 3 and -7 were detected, but pharmacological inhibition argues against a crucial role for them in the demise (Figure 2c, Supplementary Figure S3B) or clearance (Figure $7 \mathrm{~b}$ ) of the Casp9 ${ }^{-1-}$ cells. Because procaspase-3 autoactivates when the $\mathrm{pH}$ is lowered, ${ }^{29}$ the MOMP-induced acidification of the cytosol ${ }^{30}$ may produce the traces of active effector caspases.

Model for caspase-independent cell death and clearance. As Figure 9 outlines, our findings suggest that
Casp9 $9^{-/}$cells exposed to apoptotic stimuli die by caspaseindependent cell death following the mitochondrial damage controlled by the Bcl-2 family (Figures $3-5$ ). MOMP may promote caspase-independent cell death through generation of reactive oxygen species, depletion of ATP or other metabolic dysfunctions. ${ }^{22}$

Monitoring $\Delta \Psi_{\mathrm{m}}$ during apoptosis of genetically modified cells revealed two discrete phases of mitochondrial damage. The initial drop to an intermediate $\Delta \Psi_{\mathrm{m}}$ results from MOMP, as it was mediated by Bax/Bak, but not caspases (Figure 3) and shortly followed cytochrome $c$ release (Figure 4). Importantly, as reported for two other cell types, ${ }^{17,18}$ MOMP committed the cells to die, as they no longer formed colonies (Figure 5, Supplementary Figure S6), although their plasma membranes remained intact. The second phase of mitochondrial damage, hastened in wild-type cells by activated 



Figure 7 Dying Casp9 ${ }^{-1}$ thymocytes expose PS before their plasma membranes become permeable. (a) WT and Casp9 $9^{-1-}$ thymocytes were either left untreated or exposed to $5 \mathrm{~Gy}$ of $\gamma$-irradiation and cultured for $24 \mathrm{~h}$. The cells were then stained with PI and Annexin V and analyzed by FACS. The percentages of cells in each quadrant are indicated. (b) Casp ${ }^{-/-}$thymocytes were cultured ex vivo in the presence of $50 \mu \mathrm{M}$ IDN-6275 or no caspase inhibitor. The cells were stained with PI and Annexin $\mathrm{V}$ after the indicated periods of culture and analyzed by FACS. (c and d) WT (c) and Casp9 ${ }^{-1-}$ (d) thymocytes left untreated or exposed to 5 Gy of $\gamma$-irradiation were cultured for $24 \mathrm{~h}$ and then stained with PI, Annexin $\mathrm{V}$ and $\mathrm{DiOC}_{6}(3)$ and analyzed by FACS. The percentages of cells within each of the gated, color-coded subpopulations are indicated on the dot plots. Histograms representing $\Delta \Psi_{\mathrm{m}}$ are plotted for all the cells and each of the gated subpopulations. The histograms are divided into three regions $\left(\Delta \Psi_{\mathrm{m}}^{\text {high }}, \Delta \Psi_{\mathrm{m}}^{\text {intermediate }}\right.$ and $\left.\Delta \Psi_{\mathrm{m}}^{\text {low }}\right)$ defined by the dashed lines and the percentage of the analyzed cells within each region is indicated

caspases, ${ }^{16}$ ablated $\Delta \Psi_{\mathrm{m}}$ (Figure 3). The reduced $\Delta \Psi_{\mathrm{m}}$ following MOMP might not be expected, because $\Delta \Psi_{\mathrm{m}}$ reflects a hydrogen ion gradient across the inner mitochondrial membrane, and the channels in the outer membrane (e.g., VDAC) are thought to be porous to hydrogen ions. As the residual cytochrome $c$ remaining in mitochondria by diffusion after MOMP limits oxidative phosphorylation, ${ }^{31}$ the intermediate $\Delta \Psi_{\mathrm{m}}$ probably reflects reduced ATP production, whereas its total collapse probably reflects the failure of respiration (Figure 9).

We found that dying Casp $9^{-/-}$cells exposed PS while they remained intact (Figure 7), allowing their efficient phagocytosis (Figures 6 and 8) without release of noxious molecules. The PS exposure coincided with $\Delta \Psi_{m}$ collapse, in both the wild-type cells dying rapidly by caspase-dependent apoptosis and the Casp $9^{-1-}$ cells dying more slowly by a caspaseindependent mechanism (Figures $7 \mathrm{c}$ and d). This suggests that the same underlying mechanism may be engaged and that collapse of $\Delta \Psi_{\mathrm{m}}$ (i.e., respiratory failure) triggers PS exposure (Figure 9 ).
How $\Delta \Psi_{\mathrm{m}}$ collapse provokes PS exposure remains uncertain. However, as the translocase that shifts PS from the outer to the inner leaflet of the plasma membrane requires ATP, ${ }^{2}$ one appealing possibility is that the lower ATP production following MOMP, ${ }^{31}$ reduces translocase activity, allowing PS accumulation in the outer leaflet. ${ }^{25,32}$ Reduced cellular ATP presumably would also impair plasma membrane $\mathrm{Ca}^{2+}$ ATPase function, leading to $\mathrm{Ca}^{2+}$ influx and activation of the 'scramblase' thought to flip PS bi-directionally between the outer and inner leaflets of the plasma membrane. ${ }^{3}$ However, the identity and role of scamblases remains uncertain $^{32}$ and a very recent study has suggested that exposed PS may derive instead from fusion of lysosomes with the plasma membrane. ${ }^{33}$ In any case, dying cells that quickly expose PS on their surface as a consequence of caspase activation and those that do so after a lag, probably as a result of respiratory failure, were equally able to recruit phagocytes and induce engulfment of the intact cell corpse (Figures $8 \mathrm{c}$ and 9). Other signals that contribute to phagocytosis of wildtype cells, such as calreticulin exposure and downregulation 



untreated

Noxa + ABT-737

b

WT

Casp $9^{-/-}$



Forward Scatter

C

$\square$ untreated

5 Gy

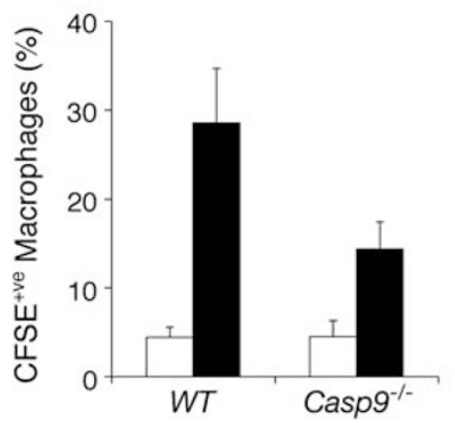



岕

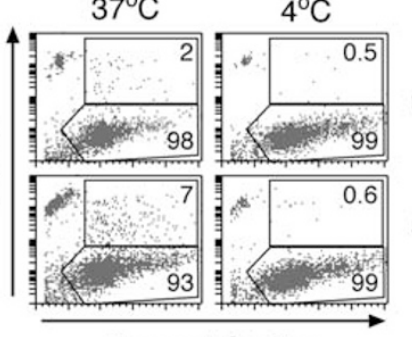

Forward Scatter untreated

5 Gy
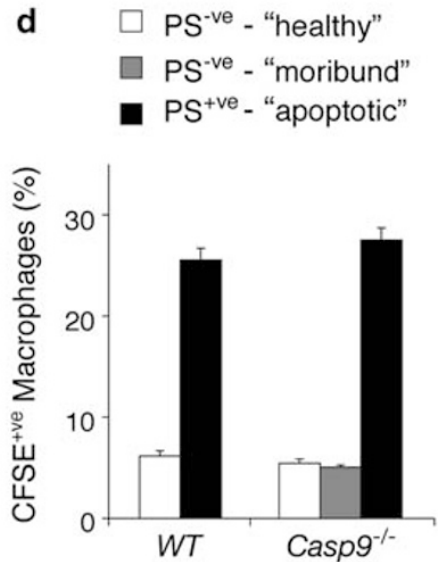

Figure 8 Phagocytes recognize and efficiently engulf dying cells with exposed PS, even Casp9 ${ }^{-/}$ones. (a) WT and Casp9 ${ }^{-1-}$ fibroblasts stably expressing Noxa were either left untreated or exposed for $24 \mathrm{~h}$ to $2.5 \mu \mathrm{M}$ ABT-737, which induces apoptosis in WT fibroblasts and causes Casp9 ${ }^{-1-}$ fibroblasts to persist in a moribund state with intact plasma membranes and damaged mitochondria (see Figure 4B, Supplementary Figure S4B). The cells were then stained as indicated with anti-calreticulin antibody, anti-CD47 antibody, or with soluble recombinant SIRP $\alpha$ ectodomain (fused to rat CD4 domains 3 and 4 ) to show that the CD47 on the fibroblasts was functional for interaction with its SIRP $\alpha$ receptor. (b) Untreated and $\gamma$-irradiated CFSE-labeled thymocytes were co-cultured with the murine $\mathrm{J} 774$ macrophage cell line for $1 \mathrm{~h}$ at either $37^{\circ} \mathrm{C}$ or on ice $\left(4^{\circ} \mathrm{C}\right.$ ). Macrophages (boxed regions) were distinguished from uningested thymocytes (CFSE ${ }^{\text {bright }}$ population with low forward scatter) by their large forward scatter (as shown here) or by staining with anti-CD11b antibodies (not shown). The percentages of macrophages that had phagocytosed one or more thymocytes were determined as the percentage of CFSE ${ }^{+v e}$ macrophages (upper boxed region) relative to the total number of macrophages. (c) Phagocytosis assays were performed as in (b). The results are presented as means \pm S.E.M. from four independent experiments. (d) Untreated and $\gamma$-irradiated CFSE-labeled thymocytes were sorted into populations enriched with 'healthy' (PS $\left.{ }^{-v e}, \Delta \Psi_{m}^{\text {high }}\right)$, 'moribund' (PS ${ }^{-v e}, \Delta \Psi_{m}^{\text {intermediate }}$ ) or 'apoptotic' (PS $\left.{ }^{+v e}, \Delta \Psi_{m}^{\text {low }}\right)$ cells. Phagocytosis assays were performed as in (b). The data are presented as means \pm S.E.M. from a representative experiment

of $\mathrm{CD} 47,{ }^{26}$ likely accelerate the process when caspases are active but do not precede PS exposure in moribund Casp9 $9^{-/-}$ cells (Figure 8a).

Implications of caspase-independent cell death. Our findings suggest that caspase activation in the intrinsic apoptotic pathway is not absolutely required for either cell death or non-inflammatory clearance. Indeed, the overall pathways in vivo in its absence and presence appear remarkably similar (Figure 9): both are triggered by MOMP, proceed through loss of $\Delta \Psi_{\mathrm{m}}$ and induce PS exposure to allow efficient phagocytosis without overt inflammation. The only obvious consequence of precluding caspase activation for thymocytes in vivo was the lag in their elimination (Figure 6), presumably reflecting a slow attrition in $\Delta \Psi_{\mathrm{m}}$ and respiration (Figure 9). The caspase-deficient cells are then most likely demolished in a non-cell autonomous fashion within the phagocyte. ${ }^{20}$

We suggest that the primary role of caspases in vertebrates is to accelerate the cell death process. Punctual cell removal undoubtedly is essential to eliminate infected cells to limit the spread of infection, as well as to sculpt certain developing 


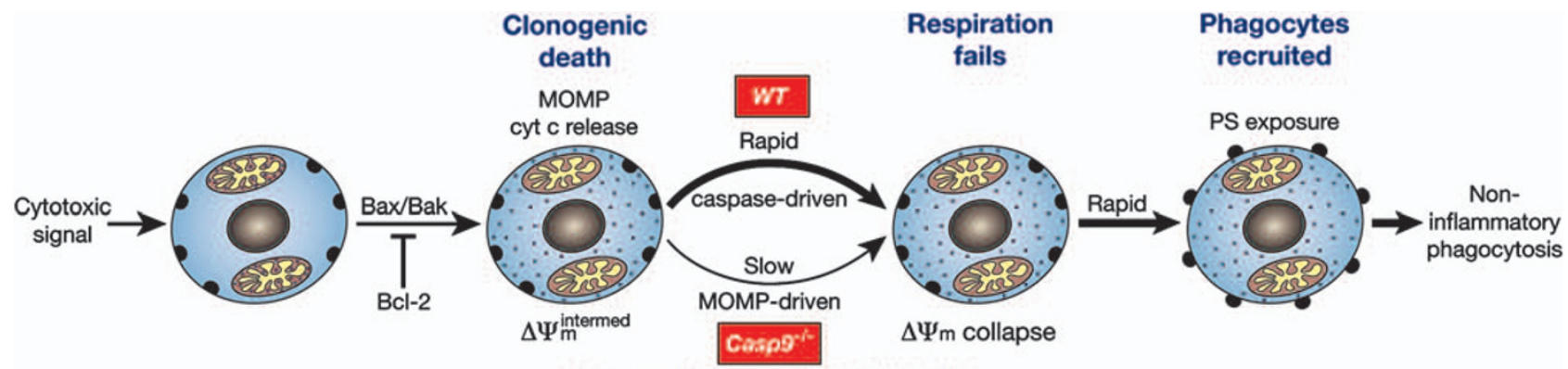

Caspase-Independent Cell Death

Figure 9 Model for cell death and non-inflammatory corpse removal without caspase activity. Irrespective of caspases, a cytotoxic signal provokes Bax/Bak-driven MOMP and cytochrome $c$ release, and the resulting reduction in respiration (reflected in an intermediate $\Delta \Psi_{\mathrm{m}}$ ) imposes clonogenic death. In $W T$ cells, the released cytochrome $c$ induces rapid caspase-driven $\Delta \Psi_{\mathrm{m}}$ collapse, PS exposure and corpse removal by professional phagocytes. In Casp9 ${ }^{-/-}$cells, the cells instead linger after MOMP in a moribund state until the impaired respiration leads to $\Delta \Psi_{\mathrm{m}}$ collapse, whereupon PS is again rapidly exposed, allowing phagocytes to recognize and engulf the corpse before its plasma membrane becomes permeable. Consequently, even without caspase activity, the cells eventually die and are cleared by non-inflammatory phagocytosis

tissues, as exemplified by the exencephaly in Casp $^{-/-}$ embryos. For many other important cell death programs, however, such as T-cell selection in the thymus, the somewhat slower MOMP-driven pathway to PS exposure apparently allows effective clearance, seemingly without inflammation or autoimmunity (Figure 9). Vertebrates may have evolved this caspase-independent cell death program as a fail-safe to eliminate cells deficient in mitochondrial function, whether due to MOMP or other types of mitochondrial damage.

Defects in clearance or degradation of apoptotic cell components can cause autoimmune disease, anemia and chronic arthritis. ${ }^{20}$ More controversially, certain tumors reportedly show alterations that would impair apoptosis downstream of MOMP, such as loss of Apaf- 1 expression, perhaps implicating impaired caspase-independent cell death in their evolution. ${ }^{22}$ Such alterations might hamper responses to cancer therapy, because the higher glycolysis in many tumor cells would render them less dependent on mitochondrial function than normal cells ${ }^{34}$ and hence more refractory to MOMP-driven death and clearance. Eradicating the most resistant tumor cells might therefore require augmenting caspase activation, for example, by targeting both the intrinsic (mitochondrial) and the extrinsic (death receptor) pathways, or enhancing their phagocytosis by devising ways to promote PS exposure, such as reducing their ATP levels ${ }^{25}$ by inhibiting glycolysis. Another avenue of attack is opened by recent evidence that certain leukemia cells evade phagocytosis and persist by not downregulating CD47, because their clearance can be enhanced with blocking CD47 antibodies. ${ }^{35,36}$ Thus, further clarification of cell clearance mechanisms should impact on the treatment of several major diseases.

\footnotetext{
Materials and Methods

Mice. The vav- $\mathrm{BCl}-2$ mice $^{37}$ were generated on an inbred $\mathrm{C} 57 \mathrm{BL} / 6$ background while Casp9 $^{+/-}$mice, ${ }^{7}$ originally generated on a mixed C57BL/6/129SV background, were backcrossed for $>12$ generations to C57BL/6 mice before intercrossing for these experiments. To circumvent the perinatal lethality of embryos lacking caspase-9, fetal liver stem cells from Casp $^{-/-}$and Casp9 ${ }^{+/+}$E14.5 embryos (on a C57BL/6-Ly5.2 background) were used to reconstitute hematopoiesis in irradiated $(2 \times 5.5 \mathrm{~Gy})$ C57BL/6-Ly5.1 recipient mice as described. ${ }^{11}$ Thymi were harvested $11-15$ weeks post-reconstitution, at which point thymocyte
}

suspensions typically comprised $>99 \%$ donor-derived $L y 5.2^{+ \text {ve }}$ cells as determined by FACS analysis.

Cell culture. All cells were cultured in DMEM supplemented with $250 \mu \mathrm{M}$ asparagine, $50 \mu \mathrm{M}$ 2-mercaptoethanol and $10 \%$ fetal calf serum. Single-cell thymocyte suspensions were prepared by passing thymus tissue through a fine wire mesh and the cells immediately cultured (at $1 \times 10^{6} \mathrm{cells} / \mathrm{ml}$ ) without further manipulation. WT and Casp9 ${ }^{-/-}$MEFs were immortalized by a $3 T 9$ culture protocol. ${ }^{38}$ MEFs stably expressing Bcl-2 were generated by electroporation (Bio-Rad Hercular, CA, USA) of an expression plasmid (pEF Flag-Bcl2/puro) ${ }^{39}$ and selection of puromycin-resistant clones, which were shown to overexpress $\mathrm{Bcl}-2$ by FACS analysis. The $\mathrm{Bax}^{-1-} / \mathrm{Bak}^{-1-} \mathrm{MEF}$ cell line was a gift from the late $\mathrm{Dr}$. SJ Korsmeyer and the J774 macrophage cell line from the late Dr. AW Harris.

Cell death assays. Apoptosis was induced in cultured thymocytes by exposure to the indicated doses of $\gamma$-irradiation (from a ${ }^{60} \mathrm{Co}$ source) or concentrations of etoposide (Pharmacia, NSW, Australia), dexamethasone (Sigma, St louis, MO, USA) or PMA (Sigma). Apoptosis was induced in MEF cultures by exposure to the indicated concentrations of etoposide, staurosporine (Sigma) or ABT-737, ${ }^{13}$ or by retroviral expression of BH3-only proteins as described. ${ }^{12}$ Cell viability was determined by staining the cells with $1 \mu \mathrm{g} / \mathrm{ml} \mathrm{PI}$ followed by FACS analysis. The caspase inhibitors IDN- $6275^{40}$ (gift of Drs. K Tomaselli and T Oltersdorf) and ZVAD-fmk (Bachem) were dissolved in DMSO and added at $50 \mu \mathrm{M}$ to cultures $1-2 \mathrm{~h}$ before exposure to the apoptotic stimulus. Clonogenic assays were performed by plating equal number of cells in separate wells, culturing them for 7 days and revealing macroscopic colonies by staining with Giemsa (Sigma).

Flow cytometric analyses and cell sorting. Cell suspensions were stained in a balanced salt solution containing $2 \%$ fetal calf serum, plus $1 \%$ rat serum when staining thymocytes. For surface staining of adherent MEF, the cells were suspended with PBS-based enzyme-free cell dissociation buffer (GIBCO, Carlsbad, CA, USA). Antibodies were obtained commercially or purified from hybridoma supernatant and conjugated in our laboratory by Dr. A Strasser. They included: anti-CD4-biotin (H129), anti-CD8-FITC (YTS169), anti-CD11b-APC (MI/ 70, Pharmingen, San Diego, CA, USA), anti-CD47 (miap301, Pharmingen) and anticalreticulin (SPA-600, Stressgen, AmArbor, MI, USA). CD4-biotin was detected with streptavidin-PE (Caltag, Carlsbad, CA, USA), CD47 with goat-anti-rat-lgG-FITC (Southern Biotech, Birningham, AL, USA), and calreticulin staining with goat-antirabbit-IgG-FITC (Southern Biotech). Annexin V-FITC and Annexin V-biotin were conjugated in our laboratory by Dr. A Strasser. Annexin V-biotin staining was detected with streptavidin-APC (Caltag). Soluble SIRP $\alpha$ ectodomian was produced by transfection of 293T cells with a construct encoding a fusion of the SIRP $\alpha$ ectodomain with the rat CD4 domains 3 and 4 and a biotinylation consensus sequence. ${ }^{41}$ The recombinant protein was biotinylated using the $E$. colienzyme BirA (Avidity) and binding detected using Streptavidin-PE (Caltag).

To assess $\Delta \Psi_{\mathrm{m}}$, cells were cultured in media containing $40 \mathrm{nM} \mathrm{DiOC}_{6}(3)$ for $15 \mathrm{~min}$ at $37^{\circ} \mathrm{C}$, harvested, placed on ice and analyzed within $1 \mathrm{~h}$. TUNEL staining 
was performed with the fluorescein In Situ Cell Death Detection Kit (Roche, Indianapolis, IN, USA) following the manufacturer's protocol. Cytochrome $c$ release was visualized as described. ${ }^{42}$ Stained cells were analyzed on a FACScan (Becton Dickinson, Franklin Lakes, USA) or FACSCalibur (Becton Dickinson), and cell populations isolated using a MoFlo cell sorter (Cytomation, Fort Collins, CO, USA).

Phagocytosis assays. $\mathrm{J} 774$ macrophages were plated at $1 \times 10^{5}$ cells per well in 24-well plates and cultured overnight. Thymocytes were labeled with $2.5 \mu \mathrm{M}$ CFSE for $7 \mathrm{~min}$ at room temperature in balanced salt solution, washed, resuspended in culture medium, either left untreated or exposed to $5 \mathrm{~Gy}$ $\gamma$-irradiation, and then cultured for $24 \mathrm{~h}$. Before co-culture, the untreated thymocytes were centrifuged over Ficoll-Paque Plus (Pharmacia) to enrich for viable (Ficoll-buoyant) cells, which were washed and resuspended in culture medium. Their viability was then typically $>90 \%$, whereas $24 \mathrm{~h}$ after $\gamma$-irradiation wild-type and Casp9 ${ }^{-1-}$ thymocytes were typically $\sim 10$ and $\sim 70 \%$ viable, respectively. CFSE-labeled thymocytes $\left(2 \times 10^{6}\right)$ were added to each well of macrophages and co-cultured for $1 \mathrm{~h}$ at $37^{\circ} \mathrm{C}$ or on ice. Macrophages were then washed with PBS to remove uningested thymocytes, resuspended with trypsinization and analyzed by flow cytometry. In the experiment using enriched fractions of thymocytes as targets (Figure 8d), untreated and $\gamma$-irradiated CFSElabeled thymocytes were stained with $\mathrm{PI}$ and sorted into $\mathrm{PI}^{+\mathrm{ve}}$ and $\mathrm{Pl}^{-\mathrm{ve}}$ fractions. The fractions designated 'healthy' were $\mathrm{PI}^{-v e}$ thymocytes sorted from untreated samples, most of which have high $\Delta \Psi_{\mathrm{m}}$ (e.g., see Figures $7 \mathrm{c}$ and d). The 'apoptotic' fractions were $\mathrm{PI}^{+ \text {ve }}$ thymocytes sorted from irradiated samples, which have low $\Delta \Psi_{\mathrm{m}}$ (e.g., see Figures $7 \mathrm{c}$ and d). The 'moribund' fractions were $\mathrm{PI}^{-\mathrm{ve}}$ thymocytes sorted from irradiated Casp ${ }^{-1-}$ thymocytes, which primarily have intermediate $\Delta \Psi_{\mathrm{m}}$ (e.g., see Figure $7 \mathrm{~d}$ ). The 'healthy' and 'moribund' fractions both contained a minor contaminating population $(<10 \%)$ of $\mathrm{PS}^{+\mathrm{ve}}$ cells, which likely contributed to the background levels of phagocytosis for these fractions. glass slides coated with HEp-2 cells (Cedarlane Diagnostics, Burlington, NC, USA). The slides were incubated at room temperature in a humid chamber for $30 \mathrm{~min}$. Antibodies bound to the slides were detected by staining with FITC-conjugated goat anti-mouse IgG (Southern Biotechnology). Slides were observed with a Zeiss Axioplan 2 fluorescence microscope and images captured using a Zeiss Axiocam and Axiovision software (Carl Zeiss, Dublin, CA, USA).

Histology and microscopic imaging. Thymus tissue was fixed in Bouin's, sectioned, and stained with hematoxylin and eosin. The sections were observed using an Optiphot microscope (Nikon) with a Plan Apo $\times 100$ (NA 1.35, oil) objective lens and images were captured with a Nikon DS camera head (DS-5M) and control unit (DS-L1) using an integral software.

Measurements of caspase activity. Cell lysates were prepared in TNE lysis buffer $(50 \mathrm{mM}$ Tris pH 7.5, $150 \mathrm{mM} \mathrm{NaCl}, 2 \mathrm{mM}$ EDTA, $1 \% \mathrm{NP}-40,1 \times$ complete protease inhibitors (Roche), $5 \mathrm{mM}$ DTT). The active caspases were labeled by exposure to $2.5 \mu \mathrm{M}$ biotin-XVAD-fmk (gift of Drs. D Nicholson and S Roy) for $30 \mathrm{~min}$ at $37^{\circ} \mathrm{C}$. The labeled caspases were either analyzed in bulk by western blotting with HRP-conjugated streptavidin or first purified with streptavidinsepharose resin (Amersham Biosciences, Piscataway, NJ, USA), and then analyzed by western blotting with antibodies recognizing active caspase-3 (Chemicon, Temecula, CA, USA), caspase-7 (1-1-11; gift of Dr. Y Lazebnik), caspase-1 (1H11; Alexis, San Diego, CA, USA), caspase-8 ${ }^{43}$ (1G12; Alexis), caspase-11 (4E11; Alexis) and caspase-12 (11F10; Alexis). For substrate assays, the lysates were assayed using Rhodamine110 Enz-Check Caspase Assay Kits (Molecular Probes, Eugene, OR, USA) according to the manufacturer's instructions with a SpectraFluor Plus plate reader (TECAN, Durhan, NC, USA).

\section{Conflict of interest}

The authors declare no conflict of interest.

Acknowledgements. We thank Professor A Strasser for discussions and valuable comments on the paper; V Marsden, L O'Reilly, S Jones and B Sheikh for reagents and advice; and G Siciliano, D Cooper, K Pioch and K Vella for animal care. DNA constructs encoding the soluble SIRP $\alpha$ ectodomain were kindly donated by Associate Professor Mark Wright (Monash University, Melbourne, Australia). This work was supported by a Melbourne University International Research Scholarship and Cancer Council Victoria Postdoctoral Research Fellowship to MvD, National Health and Medical Research Council (NHMRC) Fellowships to DCSH and JMA, and grants from the NHMRC (Program Grant 461221), the NIH (CA43540) and the Leukemia and Lymphoma Society (SCOR Grant 7413). Infrastructure support from NHMRC IRIISS Grant 361646 and the Victorian State Government OIS grant is gratefully acknowledged.

1. Kerr JFR, Wyllie AH, Currie AR. Apoptosis: a basic biological phenomenon with wideranging implications in tissue kinetics. Br J Cancer 1972; 26: 239-257.

2. Ravichandran KS, Lorenz U. Engulfment of apoptotic cells: signals for a good meal. Nat Rev Immunol 2007; 7: 964-974.

3. Schlegel RA, Williamson P. Phosphatidylserine, a death knell. Cell Death Differ 2001; 8: 551-563

4. Adams JM, Cory S. The Bcl-2 apoptotic switch in cancer development and therapy. Oncogene 2007; 26: 1324-1337.

5. Taylor RC, Cullen SP, Martin SJ. Apoptosis: controlled demolition at the cellular level. Nat Rev Mol Cell Biol 2008; 9: 231-241.

6. Hakem R, Hakem A, Duncan GS, Henderson JT, Woo M, Soengas MS et al. Differential requirement for caspase 9 in apoptotic pathways in vivo. Cell 1998; 94: 339-352.

7. Kuida K, Haydar TF, Kuan CY, Gu Y, Taya C, Karasuyama $\mathrm{H}$ et al. Reduced apoptosis and cytochrome $c$-mediated caspase activation in mice lacking caspase 9. Cell 1998; 94: 325-337.

8. Cecconi F, Alvarez-Bolado G, Meyer BI, Roth KA, Gruss P. Apaf-1 (CED-4 homologue) regulates programmed cell death in mammalian development. Cell 1998; 94: 727-737.

9. Yoshida H, Kong Y-Y, Yoshida R, Elia AJ, Hakem A, Hakem R et al. Apaf1 is required for mitochondrial pathways of apoptosis and brain development. Cell 1998; 94 : 739-750.

10. Lakhani SA, Masud A, Kuida K, Porter Jr GA, Booth CJ, Mehal WZ et al. Caspases 3 and 7: key mediators of mitochondrial events of apoptosis. Science 2006; 311: 847-851.

11. Marsden V, O'Connor L, O'Reilly LA, Silke J, Metcalf D, Ekert P et al. Apoptosis initiated by Bcl-2-regulated caspase activation independently of the cytochrome $c /$ Apaf-1/caspase- 9 apoptosome. Nature 2002; 419: 634-637.

12. Chen L, Willis SN, Wei A, Smith BJ, Fletcher JI, Hinds MG et al. Differential targeting of prosurvival $\mathrm{Bcl}-2$ proteins by their $\mathrm{BH}$-only ligands allows complementary apoptotic function. Mol Cell 2005; 17: 393-403.

13. Oltersdorf T, Elmore SW, Shoemaker AR, Armstrong RC, Augeri DJ, Belli BA et al. An inhibitor of Bcl-2 family proteins induces regression of solid tumours. Nature 2005; 435 : 677-681.

14. Zamzami N, Marchetti P, Castedo M, Zanin C, Vayssiere JL, Petit PX et al. Reduction in mitochondrial potential constitutes an early irreversible step of programmed lymphocyte death in vivo. J Exp Med 1995; 181: 1661-1672.

15. Vander Heiden MG, Chandel NS, Williamson EK, Schumacker PT, Thompson CB. Bcl- $\mathrm{X}_{\mathrm{L}}$ regulates the membrane potential and volume homeostasis of mitochondria. Cell 1997; 91: 627-637.

16. Ricci JE, Munoz-Pinedo C, Fitzgerald P, Bailly-Maitre B, Perkins GA, Yadava N et al. Disruption of mitochondrial function during apoptosis is mediated by caspase cleavage of the p75 subunit of complex I of the electron transport chain. Cell 2004; 117 : 773-786.

17. Ekert PG, Read SH, Silke J, Marsden VS, Kaufmann H, Hawkins CJ et al. Apaf-1 and caspase- 9 accelerate apoptosis, but do not determine whether factor-deprived or drugtreated cells die. J Cell Biol 2004; 165: 835-842.

18. Marsden VS, Kaufmann T, O'Reilly L A, Adams JM, Strasser A. Apaf-1 and Caspase- 9 are required for cytokine withdrawal-induced apoptosis of mast cells but dispensable for their functional and clonogenic death. Blood 2006; 107: 1872-1877.

19. Asano K, Miwa M, Miwa K, Hanayama R, Nagase H, Nagata S et al. Masking of phosphatidylserine inhibits apoptotic cell engulfment and induces autoantibody production in mice. $J$ Exp Med 2004; 200: 459-467.

20. Nagata S. Autoimmune diseases caused by defects in clearing dead cells and nuclei expelled from erythroid precursors. Immunol Rev 2007; 220: 237-250.

21. Surh CD, Sprent J. T-cell apoptosis detected in situ during positive and negative selection in the thymus. Nature 1994; 372: 100-103

22. Tait SW, Green DR. Caspase-independent cell death: leaving the set without the final cut. Oncogene 2008; 27: 6452-6461.

23. Verhoven B, Krahling S, Schlegel RA, Williamson P. Regulation of phosphatidylserine exposure and phagocytosis of apoptotic T lymphocytes. Cell Death Differ 1999; 6 : 262-270

24. Ferraro-Peyret C, Quemeneur L, Flacher M, Revillard JP, Genestier L. Caspaseindependent phosphatidylserine exposure during apoptosis of primary $T$ lymphocytes. $\mathrm{J}$ Immunol 2002; 169: 4805-4810.

25. Hirt UA, Leist M. Rapid, noninflammatory and PS-dependent phagocytic clearance of necrotic cells. Cell Death Differ 2003; 10: 1156-1164.

26. Gardai SJ, McPhillips KA, Frasch SC, Janssen WJ, Starefeldt A, Murphy-Ullrich JE et al. Cell-surface calreticulin initiates clearance of viable or apoptotic cells through transactivation of LRP on the phagocyte. Cell 2005; 123: 321-334. 
27. Marsden VS, Ekert PG, Van Delft M, Vaux DL, Adams JM, Strasser A. Bcl-2-regulated apoptosis and cytochrome $c$ release can occur independently of both caspase-2 and caspase-9. J Cell Biol 2004; 165: 775-780.

28. Rathmell JC, Lindsten T, Zong W-X, Cinalli RM, Thompson CB. Deficiency in Bak and Bax perturbs thymic selection and lymphoid homeostasis. Nat Immunol 2002; 3: 932-939.

29. Roy S, Bayly Cl, Gareau Y, Houtzager VM, Kargman S, Keen SL et al. Maintenance of caspase-3 proenzyme dormancy by an intrinsic 'safety catch'regulatory tripeptide. Proc Natl Acad Sci USA 2001; 98: 6132-6137.

30. Matsuyama S, Llopis J, Deveraux QL, Tsien RY, Reed JC. Changes in intramitochondria and cytosolic $\mathrm{pH}$ : early events that modulate caspase activation during apoptosis. Nat Cell Biol 2000; 2: 318-325.

31. Waterhouse NJ, Goldstein JC, von Ahsen O, Schuler M, Newmeyer DD, Green DR Cytochrome $\mathrm{c}$ maintains mitochondrial transmembrane potential and ATP generation after outer mitochondrial membrane permeabilization during the apoptotic process. J Cell Biol 2001; 153: 319-328.

32. Gleiss B, Gogvadze V, Orrenius S, Fadeel B. Fas-triggered phosphatidylserine exposure is modulated by intracellular ATP. FEBS Lett 2002; 519: 153-158.

33. Mirnikjoo B, Balasubramanian K, Schroit AJ. Suicidal membrane repair regulates phosphatidylserine externalization during apoptosis. J Biol Chem 2009; 284: 22512-22516.

34. Colell A, Ricci JE, Tait S, Milasta S, Maurer U, Bouchier-Hayes L et al. GAPDH and autophagy preserve survival after apoptotic cytochrome $c$ release in the absence of caspase activation. Cell 2007; 129: 983-997.

35. Jaiswal S, Jamieson CHM, Pang WW, Park CY, Chao MP, Majeti R et al. CD47 is upregulated on circulating hematopoietic stem cells and leukemia cells to avoid phagocytosis. Cell 2009; 138: 271-285.
36. Majeti R, Chao MP, Alizadeh AA, Pang WW, Jaiswal S, Gibbs Jr KD et al. CD47 is an adverse prognostic factor and therapeutic antibody target on human acute myeloid leukemia stem cells. Cell 2009; 138: 286-299.

37. Ogilvy S, Metcalf D, Print CG, Bath ML, Harris AW, Adams JM. Constitutive bcl-2 expression throughout the hematopoietic compartment affects multiple lineages and enhances progenitor cell survival. Proc Natl Acad Sci USA 1999; 96 : 14943-14948.

38. Todaro GJ, Green H. Quantitative studies of the growth of mouse embryo cells in culture and their development into established lines. J Cell Biol 1963; 17: 299-313.

39. Huang DCS, Cory S, Strasser A. Bcl-2, Bcl- $X_{L}$ and adenovirus protein E1B19kD are functionally equivalent in their ability to inhibit cell death. Oncogene 1997; 14 405-414.

40. Wu JC, Fritz LC. Irreversible caspase inhibitors: tools for studying apoptosis. Meth Enzymol 1999; 17: 320-328.

41. Brown MH, Boles K, van der Merwe PA, Kumar V, Mathew PA, Barclay AN. 2B4, the natural killer and $T$ cell immunoglobulin superfamily surface protein, is a ligand for CD48. J Exp Med 1998; 188: 2083-2090.

42. Waterhouse NJ, Trapani JA. A new quantitative assay for cytochrome $c$ release in apoptotic cells. Cell Death Differ 2003; 10: 853-855.

43. O'Reilly LA, Divisekera U, Newton K, Scalzo K, Kataoka T, Puthalakath $\mathrm{H}$ et al. Modifications and intracellular trafficking of FADD/MORT1 and caspase-8 after stimulation of T lymphocytes. Cell Death Differ 2004; 11: 724-736.

44. Hibbs ML, Tarlinton DM, Armes J, Grail D, Hodgson G, Maglitto R et al. Multiple defects in the immune system of Lyn-deficient mice, culminating in autoimmune disease. Cell 1995 83: $301-311$

\section{Supplementary Information accompanies the paper on Cell Death and Differentiation website (http://www.nature.com/cdd)}

